\title{
Measuring the relative performance in mining industry: A case study of cooperative Seif mining company
}

\author{
Mohammad Reza Lotfi ${ }^{\text {a }}$ Mahdi Hosseini Ghadikolaee and Khodabakhsh Hemmati*
}

Department of Management, Firoozkuh Branch, Islamic Azad University, Firoozkuh, Iran

\section{H R O N I C L E}

\section{Article history:}

Received May 15, 2013

Received in revised format

25 June 2013

Accepted 7 August 2013

Available online

August 72013

Keywords:

PEST

$B S C$

Seif cooperative mining

Performance measurement

\begin{abstract}
A B S T R A C T
In this paper, we present an empirical study to measure the performance of a salt refinery named Seif cooperative mining. The study uses Political-Economical-SocialTechnological Analysis (PEST) technique to evaluate opportunities and threats associated with external as well as internal factors influencing the firm. The study designs a questionnaire in Liket scale and asks decision maker to evaluate internal/external threats. In terms of external factors, there are four opportunities and ten threats associated with External factor evaluation (EFE) factors. In terms of opportunities, existing potential for export has received the highest priority followed by easy access to national transportation and government support. On the threats part, firm's dependency on importing necessary parts, global price reduction and mineral reserve termination in near future are the most important issues. In addition, in terms of internal factors, on the opportunity part, access to necessary utilities is considered as the most important factor followed by availability of high level lab equipment and sufficient assets and equities. On the threats, depreciation is considered as the most important issue followed by lack of optimum utilization of equipment and lack of enterprise resource planning. In addition, the study uses balanced score card (BSC) technique to look at the performance of the firm in terms of learning and growth, internal process, customer and financials. The study determines the present and ideal status of the firm.
\end{abstract}

\section{Introduction}

Measuring the performance of any organization plays an important role on the success of any organization (Kravchuk \& Schack, 1996). For years, the performance of business units was only adjusted based on financial figures. However, financial data alone do not represent the actual performance of a firm especially when the firm is in its early stage. Balanced scorecard (BSC), on the 
other hand, is an alternative method to measure the performance of organization not only based on financial data but also by considering other important issues (Kaplan \& Norton, 1992, 2000, 2002, 2004). In fact, a firm needs to have the ability for learning and growth; it must have strong internal process and must maintain strong relationship with its customers. BSC technique has the ability to consider all these perspectives and it has widely been used among practitioners in various organizations.

The design and implementation of Performance Measurement Systems (PMS) have been widely studied in management studies. However, recent work has highlighted the potential importance of treating design and implementation not as separate dimensions, but rather as entangled perspectives. Agostino and Arnaboldi (2012) concentrated on a BSC to explore how implementation of the PMS was interrelated with its design dimension. In investigating PMS implementation, they adopted BSC as a framework of analysis as a distinction between diagnostic and interactive control and used the proposed model for a two year multiple case study of seven Italian companies.

Creamer and Freund (2010) demonstrated how the boosting technique can be applied to define a datadriven board BSC with applications to S\&P 500 companies. Using Adaboost, they generated alternating decision trees (ADTs), which describe the relationship between corporate governance variables, and firm performance. They also proposed a method to build a representative ADT based on cross-validation experiments. The representative ADT chose the most critical indicators for the board BSC and they proposed a partially automated strategic planning system combining Adaboost with the board BSC for board-level or investment decisions. Kloot and Martin (2000) reported on research into performance management systems in local government using BSC method. Lin et al. (2012) presented an integrated hierarchical BSC with fuzzy linguistic for evaluating operating room performance in hospitals. Danaei and Omidifard (2013) presented a strategic planning and performance measurement using BSC for a case study of Iran Kaolin and Barite company.

\section{The proposed study}

In this paper, we present an empirical study to measure the performance of a salt refinery named cooperative Seif mining. The mining firm is an aggregation manufacturer of industrial salt, edible salt mine in the Middle East and it is the three largest salt plants in province of Semnan, Iran. The proposed study of this paper determines internal/external weakness/strength of a mining firm located in province of Semnan, Iran. In our survey, we have selected 37 managers from management team as internal experts and four customers as external experts to evaluate these factors. The survey has designed a questionnaire based on these factors in Likert scale and we have asked them to assign a priority from Low (1) to High (5) to each criterion. After normalizing all criteria, we have determined the coefficients and rank associated with each opportunity/threats. In addition, the study uses balanced score card (BSC) technique to look at the performance of the firm in terms of learning and growth, internal process, customer and financials. The study determines the present and ideal status of the firm.

\section{The results}

Table 1 demonstrates external factor evaluation (EFE) for this firm. All opportunities and threats are determined based on Political-Economical-Social-Technological (PEST) technique (Schwarz \& Thompson, 1990). As we can observe from the results of Table 1, there are four opportunities and ten threats associated with External factor evaluation (EFE) factors. In terms of opportunities, existing potential for export has received the highest priority followed by easy access to national transportation and government support. On the threats, firm's dependency on importing necessary parts, global price reduction and mineral reserve termination in near future are the most important issues. 
Table 1

External factor evaluation (EFE) for criteria associated with the proposed study

\begin{tabular}{llrcc}
\hline External main factors & coefficient & rank & score \\
\hline \multirow{5}{*}{ Opportunities } & 1. Easy access to network transportation & 0.0577 & 3 & 0.17 \\
& 2. Existing potential for export & 0.0962 & 4 & 0.38 \\
& 3. Availability of getting permission for supplying raw materials & 0.0769 & 3 & 0.23 \\
& 4. Opportunity to receive government support & 0.0769 & 3 & 0.23 \\
\hline & 1. Environmental issues & 0.0385 & 1 & 0.04 \\
& 2. Dependency on importing necessary parts & 0.0962 & 4 & 0.48 \\
& 3. Energy subsidy removal & 0.0769 & 3 & 0.23 \\
& 4. Lack of possibility for ordering necessary materials from inside country & 0.0769 & 4 & 0.31 \\
& 5. Shortage of appropriate raw materials & 0.0769 & 4 & 0.31 \\
\multirow{5}{*}{ Threats } & 6. Global price reduction & 0.0962 & 3 & 0.29 \\
& 7. Mineral reserve termination in near future & 0.0962 & 4 & 0.48 \\
& 8. International embargo & 0.0577 & 4 & 0.23 \\
& 9. Increase in custom rates & 0.0385 & 1 & 0.04 \\
& 10. High rate of financing and difficulty on access to necessary working capital & 0.0385 & 2 & 0.08 \\
\hline & & 1 & - & 3.5 \\
\hline
\end{tabular}

Table 2

Internal factor evaluation (IFE) for criteria associated with the proposed study

\begin{tabular}{llccc}
\hline External main factors & coefficient & rank & score \\
\hline \multirow{5}{*}{ Opportunities } & 1. Existing of expert in salt industry & 0.0833 & 4 & 0.33 \\
& 2. Sufficient assets and equities & 0.1111 & 1 & 0.11 \\
& 3. Global brand & 0.0566 & 3 & 0.17 \\
& 4. Shareholder combination & 0.0278 & 4 & 0.11 \\
& 5. Availability of high level lab equipment & 0.1389 & 2 & 0.28 \\
& 6. Access to necessary utilities such as gas, electricity, etc. & 0.1667 & 3 & 0.50 \\
\hline \multirow{3}{*}{ Threats } & 1. Depreciation of some equipment & 0.1111 & 4 & 0.44 \\
& 2. Lack of access to enterprise resource planning & 0.0556 & 1 & 0.06 \\
& 3. Lack of optimum utilization of equipment & 0.0833 & 3 & 0.25 \\
& 4. Inappropriate layout design & 0.0278 & 4 & 0.11 \\
\hline Total & & 1 & - & 2.36 \\
\hline
\end{tabular}

Similarly, we have determined 6 opportunities and four threats as internal factor evaluation (IFE) shown in Table 2. On the opportunity part, access to necessary utilities is considered as the most important factor followed by availability of high level lab equipment and sufficient assets and equities. On the threats, depreciation is considered as the most important issue followed by lack of optimum utilization of equipment and lack of enterprise resource planning.

\section{Table 3}

Performance measurement of organization based on BSC method

\begin{tabular}{|c|c|c|c|c|c|c|c|c|}
\hline Perspective & Process & Attribute & Unit & $+/-$ & Present & Ideal & Score & Performance \\
\hline \multirow{3}{*}{$\begin{array}{l}\text { Learning \& } \\
\text { Growth }\end{array}$} & Environment & Training program to keep environment & Person/hour & + & 0 & 100 & $0 \%$ & \multirow{3}{*}{$8 \%$} \\
\hline & Environment & Number of granted certificate on environment & Certificate & + & 0 & 1 & $0 \%$ & \\
\hline & Training/Research & Number of training programs & Person/hour & + & 150 & 600 & $25 \%$ & \\
\hline \multirow{6}{*}{$\begin{array}{l}\text { Internal } \\
\text { Process }\end{array}$} & \multirow{2}{*}{$\begin{array}{l}\text { Process } \\
\text { planning }\end{array}$} & Percentage increase in mining utilization & Percent & + & 5 & 60 & $8 \%$ & \\
\hline & & Percentage pert reduction & Percent & - & 30 & 10 & $33 \%$ & \\
\hline & \multirow{2}{*}{$\begin{array}{l}\text { Productivity } \\
\text { operations }\end{array}$} & Percentage reduction in fuel & Percent & + & 5 & 20 & $25 \%$ & \multirow[t]{2}{*}{$24 \%$} \\
\hline & & Applying new technology to reduce consumption & System & + & 0 & 2 & $0 \%$ & \\
\hline & \multirow{2}{*}{$\begin{array}{l}\text { Research \& } \\
\text { development }\end{array}$} & Number of international certificates & Certificate & + & 1 & 2 & $50 \%$ & \\
\hline & & Number of advanced management techniques & System & + & 1 & 4 & $25 \%$ & \\
\hline \multirow[t]{2}{*}{ Customer } & \multirow[t]{2}{*}{ CRM } & Level of customer satisfaction & Qualitative & + & 5 & 7 & $71 \%$ & \multirow[t]{2}{*}{$86 \%$} \\
\hline & & The quality of products & Degree & + & 1 & 1 & 100 & \\
\hline \multirow[t]{2}{*}{ Financial } & \multirow[t]{2}{*}{ Accounting } & Percentage reduction in operating expenses & Percent & + & 15 & 30 & $50 \%$ & \multirow[t]{2}{*}{$46 \%$} \\
\hline & & Percentage increase in productivity & Percent & + & 5 & 12 & $42 \%$ & \\
\hline \multicolumn{3}{|c|}{ Mean performance } & & & & & & $52 \%$ \\
\hline \multicolumn{3}{|c|}{ Gap performance } & & & & & & $48 \%$ \\
\hline
\end{tabular}


In Table 3, when the attribute has a positive identity, score is calculated as a ratio of present status on ideal status. For instance, for the attribute "percentage increase in mining utilization", score is calculated as $5 / 60 \times 100=8 \%$. Similarly, when the attribute maintains a negative identity, score is calculated as a ratio of ideal status on present status. For example, for the attribute "percentage per reduction”, score is calculated as $10 / 30 \times 100=33.33 \%$.

\section{Conclusion}

Measuring the relative performance of financial firms has been a major concern in today's competitive world. In this paper, we have presented an empirical investigation to determine all external/internal opportunities and threats surrounding one of the largest producers of natural salt in Middle East. In terms of opportunities, existing potential for export has received the highest priority followed by easy access to national transportation and government support. On the threats, firm's dependency on importing necessary parts, global price reduction and mineral reserve termination in near future are the most important issues. In terms of internal factors, on the opportunity part, access to necessary utilities is considered as the most important factor followed by availability of high level lab equipment and sufficient assets and equities. On the threats, depreciation is considered as the most important issue followed by lack of optimum utilization of equipment and lack of enterprise resource planning. The study has also used BSC technique to measure the performance of the firm in terms of four criteria including learning and growth, internal process, customer and financial figures. The firm seems to performed poorly in terms of learning and growth, but has good performance in terms of customer's perspective.

\section{References}

Agostino, D., \& Arnaboldi, M. (2012). Design issues in Balanced Scorecards: The "what" and "how" of control. European Management Journal, 30(4), 327-339.

Creamer, G., \& Freund, Y. (2010). Learning a board Balanced Scorecard to improve corporate performance. Decision Support Systems, 49(4), 365-385.

Danaei, A., \& Omidifard, A. (2013). Strategic planning and performance measurement using balanced scorecard: A case study of Iran Kaolin and Barite company. Management Science Letters, 3(6), 1655-1658.

Kaplan, R.S., \& Norton, D.P. (1996). Using the balanced scorecard as a strategic management system. Harvard Bus. Review (January.February). 74(1), 75-85.

Kaplan, R.S., \& Norton, D.P. (2000). The strategy-focused organization: How balanced scorecard companies thrive in the new business environment. Harvard Bus. School Press.

Kaplan, R.S., \& Norton, D.P. (2002). Building the Balanced Scorecard in Public Sector. Balanced Scorecard Report from Interview with Rick Pagsibigan, September 19.

Kaplan, R.S., \& Norton, D.P. (2004). Strategy maps: Converting intangible assets into tangible outcomes. Boston, MD: Harvard Bus. School Press.

Kloot, L., \& Martin, J. (2000). Strategic performance management: A balanced approach to performance management issues in local government. Management Accounting Research, 11(2), 231-251.

Kravchuk, R. S., \& Schack, R. W. (1996). Designing effective performance-measurement systems under the Government Performance and Results Act of 1993. Public Administration Review, 348358.

Lin, Q. L., Liu, L., Liu, H. C., \& Wang, D. J. (2012). Integrating hierarchical balanced scorecard with fuzzy linguistic for evaluating operating room performance in hospitals. Expert Systems with Applications, 40(6), 1917-1924.

Schwarz, M., \& Thompson, M. (1990). Divided we stand: Redefining politics, technology and social choice. Univ of Pennsylvania Press. 